\title{
An Assessment of Natural Regeneration of Non Timber Forest Product (NTFP) Species: A Case Study of Mandla, India
}

\section{Satvant Kaur Saini*, Kunal Bharat, Priyanshu Thapliyal, Swapan Mehra ${ }^{3}$}

IORA Ecological Solutions Pvt. Ltd., 225/164 B, LadoSarai, New Delhi-110030

Study Area: Ghughri block, Mandla, Madhya Pradesh, India

Coordinates: $22^{\circ} 67^{\prime} 85^{\prime \prime} \mathrm{N}$; 80 $68^{\prime} 95^{\prime \prime} \mathrm{E}$

Key words: Traditional Sustainable Harvesting Practices, Joint Forest Management Committees, Sustainable Harvesting Techniques.

DISCLAIMER: This study is made possible by the support of the American People through the USAID. The content are the responsibility of IORA Ecological Solutions and do not necessarily reflect the views of USAID of the United States Government.

\begin{abstract}
Non-Timber Forest Products (NTFPs) are the major source of income for rural communities, who are living in the forest fringe villages. Status of NTFPs is deteriorating in-situ in natural forests in almost every part of the country, because of commercialization of wild/herbal species of economic importance. Present study highlights the impact of harvesting on the status of utilizable plant species in their natural habitat along with its future status. The project site was Ghughri block of Mandla district, of Madhya Pradesh State. An ecological study was made in the year 2015 in the natural forests where the user's communities were harvesting NTFPs for their subsistence. Attempts were made to assess the impact of present harvesting trend on growth and natural regeneration of important plant species. Results revealed the status of NTFP trees is depleting in the project area and total 37 tree species were recorded in the standing tree crop of which 13 species were of NTFP tree category. It is evident from the data that regeneration of more than $30 \%$ of NTFPs was found to be depleting from the standing tree crop. Further, it has been observed that the species which are in trade/ commercialized, their regeneration was found to be declining as compared to the species which are being used at the household level. In the present study, efforts were made to highlight the impact of destructive harvesting and ignorance of sustainable harvesting techniques on the status of NTFP tree species and their regeneration.
\end{abstract}

Contribution of NTFPs to the forestry sector is significant as per the recent valuation was undertaken by the Ministry of Environment \& Forest in India. According to the estimates of MoEF, Govt. of India, 220 million tons fuel wood, 250 million tons of grass and green fodder and 12 million $\mathrm{m}_{3}$ of timber are removed from India's forests annually for in excess of sustainable production. These products have been estimated to be worth the US \$ 10 billion (Mukherjee, 1994). NTFP provide about $40 \%$ of total official forest revenues and $55 \%$ of forest-based employment. In Madhya Pradesh NTFP which are primarily collected by tribal women are worth more than the US \$ 700 million (Rs.30 billion) annually (World Watch, 1991). In another study from Raipur district of Madhya Pradesh, Chopra (1994) assessed the household 
income from the collection of NTFP items (Aonla, Chironjee, Harra, Honey, Kusum, Lac, Mahua, Sal seed, Tendu leaf) worth INR.29,001.54 per year. This does not account for many other NTFP items, which are collected in small quantities and are either consumed locally or sold for cash income. However, in one other study made by Malhotra et al. (1991) estimated the income of NTFP s from Rs. 234 to Rs. 5569 (\$ 8 to \$ 186) per ha with a mean of Rs. 2299 (\$79). These studies indicated that export earnings from NTFP on an average accounted for about $75 \%$ of total forest export revenue in India.

Ghughri block of Mandla district, of Madhya Pradesh State, is the area dominated by tribal rural communities mostly Gond and Baiga tribes (Dikshit \& Kala, 2014). The traditional farming system is the main occupation of people of the area, which is mostly rain fed and insufficient, along with this these villagers also collect some NTFPs from their surrounding natural forests and sell it in local village market to fulfill their daily requirements (Gautam et al., 2014). It has been observed in last about more than 2 decades that NTFPs are being commercialized and local people of the area being forced to collect the maximum quantum of utilizable plant part of valuable species by ignoring their traditional sustainable harvesting practices. These destructive harvesting practices not only depleting the prevailing status of forest resources but also impacting the regeneration and natural habitat (Pandey \& Saini, 2008; Pandey et al., 2009).

The present study is the part of a project IEMaC (Innovation in Ecosystem Management and Conservation 2014-2017) supported by USAID in which efforts are being made to develop a system of sustainable harvesting of NTFPs with an active involvement of users' communities, who are also the members of Joint Forest Management Committees (JFMCs). JFMC members are being sensitized and aware with their rights and responsibilities for sustainable management and conservation of forest resources in allotted RDF (Rehabilitation of Degraded Forest) area. An extensive survey was made in the surrounding RDF of the project area to assess the status of forest resources in-situ based on their regeneration pattern. Efforts are being made to aware the users' community with the impact of their destructive harvesting practices on future of the forest resources..

\section{Methodology:}

Study area: the present project site was in the Ghughri range of East Mandla Forest Division of Madhya Pradesh. Mandla district of Madhya Pradesh represent the forests of dry deciduous Teak, Moist deciduous Sal dominated and dry deciduous mixed forests which consist of Teak, Sal and miscellaneous forest with few patches of bamboo as undergrowth. However, as per the classification of Champion \& Seth (1968), forests of the project area falls under Southern Mixed Deciduous forests $(3 \mathrm{C} / \mathrm{C}-3)$ and
Southern tropical Dry Deciduous forests (5A) (Shrivastava, 2010). Moreover, for detailed project activities 25 project villages and 3 control villages were selected in Ghughri block of Mandla district and area covering $5 \mathrm{~km}$ buffer from the habitation site of the project villages have been marked as project area and a GIS map of the area have been prepared (Map-1)

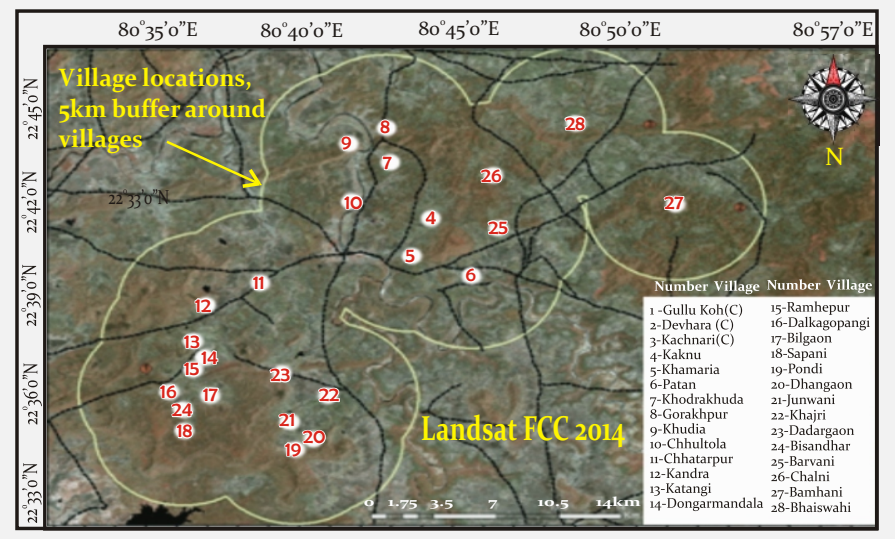

Map 1: False colour composite landsat satellite imagery showing village location with $5 \mathrm{~km}$ buffer at Ghughri tehsil, dist.- Mandla

To assess the status of forest resources in the project site entire forest area (423.7 sq $\mathrm{km}$ ) has been divided into 3 different zones based on distance from habitation site i.e. o-1 km, 1-3 km and 3-5 km from the village/habitation. Data were collected from all the 3 zones in 3 different layers, on (i) treelayer, (ii) regeneration, shrub, climber layer and (iii) ground flora covering seedling structure by employing quadrat method. Quadrats of o.1 ha were laid in each zone ( 15 plots in each zone and total 45 quadrats of 0.1 ha) for assessing the status of tree species, in each 0.1 ha plots 5 sub-plots of $10 \mathrm{~m} \times 10 \mathrm{~m}$ were laid for assessment of regeneration status and in each $10 \mathrm{~m} \times 10 \mathrm{~m}$ sized plots 5-5 plots of $1 \mathrm{~m} \mathrm{x} 1 \mathrm{~m}$ were laid for assessing the ground flora and seedling structure of various tree species (Mishra, 1968, Smith, 1983) (Fig.1). Collected data were further processed and analytical values i.e. Average density/ha, frequency percent of the species and Importance Value Index of various species were assessed through standard ecological methods (Mishra, 1968; Smith, 1983). However, a number of plots in each zone and its location was identified by using Stratified Random Sampling method, forest type and village location was the strata chosen for a sampling of plots further Arc-GIS software was used for mapping and identifying the location of plots (Map-1)

Survey Method: forest area covering $5 \mathrm{~km}$ buffer from the habitation site of the selected project villages have been marked as a project area, this is about $423.7 \mathrm{sq} \mathrm{km}$, and a GIS map of the area have been prepared. To collect the baseline data of vegetation of the project area studies were conducted in the month of June, 2015. Project area have been explored extensively by the team of experts of IORA Ecological Solutions, New Delhi for phytosociological 
assessments in Mandla region of Madhya Pradesh. Ecological assessment of the current forest biomass stock, forest regeneration status, etc. have been done for the delineated study area of the project site of Ghughri block in Mandla district of Madhya Pradesh. Stratified random sampling method has been adopted to assess the ecological status of forests of the project area. Studies were made by adopting standard ecological methods (Smith et al., 1983, Mishra, 1968). However, standard ecological methods are given in the National Working Plan Code 2014 have also taken into consideration as the base which is the same as described by Forest Survey of India (FSI).

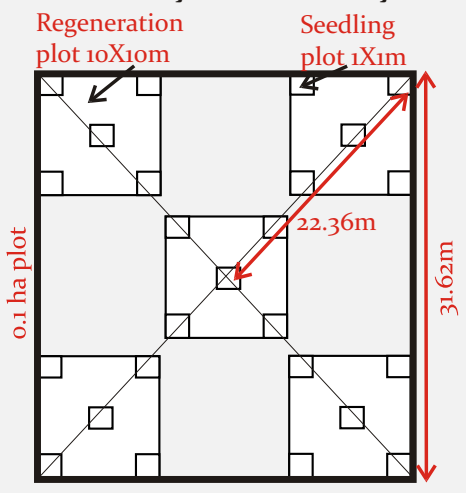

Fig.(1): Sample plot design

To assess the status of forest resources in the project site entire forest area ( $423.7 \mathrm{sq} \mathrm{km}$ ) has been divided into 3 different zones based on distance from habitation site i.e. o-1 km, 1-3 km and 3-5 km from the village/habitation. Data were collected from all the 3 zones in 3 different layers, on (i) tree layer, (ii) regeneration, shrub, climber layer and (iii) ground flora covering seedling structure by employing quadrat method. Quadrats of 0.1 ha were laid in each zone ( 15 plots in each zone and total 45 quadrats of 0.1 ha) for assessing the status of tree species, in each 0.1 ha plots 5 sub-plots of $10 \mathrm{~m} \times 10 \mathrm{~m}$ were laid for assessment of regeneration status and in each $10 \mathrm{~m} \times 10 \mathrm{~m}$ sized plots 5-5 plots of $1 \mathrm{~m} \times 1 \mathrm{~m}$ were laid for assessing the ground flora and seedling structure of various tree species (Mishra, 1968, Smith, 1983 etc.) (Fig.-1). Collected data were further processed and analytical values i.e. Average density/ha, frequency percent of the species and Importance Value Index of various species were assessed through standard ecological methods (Mishra, 1968, Smith, 1983 etc.). However, a number of plots in each zone and its location was identified by using Stratified Random Sampling method, forest type and village location was the strata chosen for a sampling of plots further Arc-GIS software was used for mapping and identifying the location of plots (Map-1).

\section{Results:}

Data on tree vegetation, their regeneration, the status of NTFP trees and their sapling and seedling structures were assessed. It is revealed from the data of tree layer that the area close to the habitation have a higher impact on tree vegetation whereas, the forest area far from habitation site have a higher number of tree species and average density (Table:1). Though similar trend was also noticed for regeneration, shrubs, and saplings as well as for ground herb and seedling layer till 1-3 km sub-impact zone, but in 3-5 km, sub-impact zone average density was found decreasing when compared with a 1-3 km sub-impact zone. Regeneration status of various tree species was also studied in all the 3 sub-impact zones of the project area. It has been noticed that in a o-1 km sub-impact zone, out of 24 standing tree crop regeneration of 7 species i.e. Acacia nilotica, Adina cordifolia, Aegle marmelos, Lannea grandis, Madhuca latifolia, Mitragyna parviflora, Stereospermum suaveolens was absent. However, seedlings of some of these species were recorded in this zone. It can be said that though the seedlings of some of these species germinate in this zone but due to heavy biotic pressure human and grazing etc. these species could not develop into established recruits or tree species. This indicates that in the future forest these species will be absent from the forest floor. Similarly, in 1-3 km subimpact zone, saplings of Albizia process, Careya arborea, Bauhinia retusa, Ficus glomerata were missing. However, instead of this saplings of some other species (other than this zone) i.e. Acacia nilotica, Aegle marmelos, Carissa spinosa, Cassia fistula, Catunaregum spinosa, Elaeodendron glaucum, Sacopetalum tomentosum, were recorded in this zone which indicates that area is more protective than the previous zone which supports the germination and establishment of recruits of tree species.

Tree vegetation in 3-5 km sub-impact zone contribute the average density of 362.11 trees/ha of 30 tree species and seems to be comparatively rich in tree diversity. But regeneration (saplings) of 9 species were absent in this zone i.e. Buchanania lanzan, Careya arborea, Casearia graveolense, Ficus benghalensis, Ficus infectoria, Lannea coromendalica, ougeinia oojeinensis, Semecarpus anacardium, Xylia xylocarpa. However, along with this sapling of some other species which are not available in the standing tree layer i.e. Gardenia latifolia, Adina cordifolia, Acacia nilotica, Butea superba (woody climber and locally rare)werealso recorded in this zone.

\begin{tabular}{|c|c|c|c|c|c|c|}
\hline $\begin{array}{l}\text { Sub- } \\
\text { impact }\end{array}$ & Trees & Species & $\begin{array}{l}\text { Regener } \\
\text { climber: }\end{array}$ & $\begin{array}{l}\text { ration/Shrub } \\
\text { rs }\end{array}$ & $\begin{array}{l}\text { Seedling } \\
\text { herbs }\end{array}$ & gs \& ground \\
\hline Zone & Species & Av.Den./ha & Species & Av. Den/ha & Species & Av.Den./ha \\
\hline o-1 km & 24 & 338.18 & 28 & 2618.18 & 39 & 64628.57 \\
\hline 1-3 km & 27 & 350.67 & 37 & 11401.07 & 42 & 116613.33 \\
\hline $3-5 \mathrm{~km}$ & 30 & 362.11 & 33 & 4820 & 33 & 104586.67 \\
\hline
\end{tabular}

Status of NTFPs: NTFPs have been recognized as the major 
source of livelihood in the remote areas which are near to forests, where there is no other source of livelihood except agriculture on limited land. With the increased human population and limited resources, pressure on existing NTFPs is increasing and sometimes people initiate the illicit felling of trees too for their subsistence, which has direct impact on future forests of the area.

The present study revealed that the Status of NTFP species is being impacted by the increased population, and the area which is closer to habitation have fewer species and their population whereas, the forest zone which is far from habitation site have comparatively better conditions (Table-1).

In the project area, 37 species of standing tree crop were recorded of which 13 species $(35 \%)$ were of NTFP importance. NTFP species recorded in the project area were Aegle marmelos, Buchanania lanzan, Cassia fistula, Catuneregum spinosa, Diospyros melanoxylon, Madhuca latifolia, Phyllanthus embelica, Pterocarpus marsupium, Schleichera oleosa, Semecarpus anacardium, Syzygium cumini, Terminalia chebula, Terminalia Billerica (Table:2) irrespective of sub-impact zones.

It is evident from the data of present study that 13 NTFP species of tree category were recorded in the project area of Ghughri block of Mandla district, whereas, regeneration status was found to be depleting from $30-50 \%$ of the standing crop in various sub-impact zones (Table-1). Moreover, it has been observed that the species which are in trade/ commercialized, their regeneration is declining more as compared to the species which are being used at a household level. Species which have declining trend of regeneration are Madhuca latifolia, Phyllanthus embelica, Buchanania lanzan, Pterocarpus marsupium, Aegle marmelos, Cassia fistula etc.However, similar findings were also reported by other researchers in Mandla district (Chaubey, 2012). Causes of declining trend of regeneration were observed to be high biotic pressure, ignorance of traditional sustainable harvesting practices, destruction of habitat, competition for collection among community members, poverty, increasing population, a limited number of fruiting trees, and over and above all is immature, and destructive harvesting trend. It has been experienced during field studies and also reported by other researchers that the users' community members' were unaware of the impact of destructive harvesting and ignorance of sustainable harvest levels is prevalent among them in the project area (Prasad et.al, 2002, Pandey et.al, 2009; Kala, 2011; Chaubey, 2012).

Due to increased human population and limited resources pressure on existing NTFPs is increasing, therefore, promotion of NTFPs through productivity improvement and value addition is necessary to manage/control this trend. User communities to be trained for improving the product value by adopting primary

processing, grading, and storage etc. to increase the shelf life of collected produces and fetch better prices with sustainable management to conserve the forest resource. In this regard, attempts are also being made to develop value chain and market linkages for NTFP species and a Rapid Market Assessment (RMA) were made based on the commercial trade and availability of surplus amount of collected produces. The study revealed that there is a scope of market linkages for NTFP species as the villagers' sell theirs produces to the intermediation at very low prices at village level for their subsistence. However, the big traders and these intermediator are the people who are making the actual benefit of the collected produces. As per the RMA report 10 species were identified for market linkages of which 8 species were of tree category, attempts were made to evaluate the status of these selected NTFP species in the natural forests of the project area (Table:3).

It is revealed from the (Table-3) that out of identified 8 NTFP species status of Tamarindus indica, Phyllanthus embelica, Syzygium cumini, Aegle marmelos and Semecarpus anacardium is critical based on their sapling and seedling conditions.

Moreover, impact on regeneration of NTFPs have been noticed higher in the o-1 km sub-impact zone as out of 8 species; 5 species were devoid of saplings and 3 were no seedlings, whereas in 1-3 sub-impact zone regeneration status of NTFPs seems to be good as compared to the previous zone. Similarly, in the 3-5 km sub-impact zone, saplings of Buchanania lanzan, Semecarpus anacardium and Tamarindus indica was absent, however, in seedling stage, Madhuca latifolia and Phyllanthus embelica were also absent from this zone.

List of tree species of standing crop in project area of Ghughri block of Mandla district, Madhya Pradesh.

Aegle marmelos

Acacia nilotica

Adina cordifolia

Albizia procera

Anogeissus latifolia

Bauhinia retusa

Buchanania lanzan

Butea monosperma

Caseariagraveolense

Cassia fistula

Catuneregam spinosa

Diospyros melanoxylon

Diospyros montana

Elaeodendron glaucum

Ficus benghalensis

Ficus glomerata

Ficus infectoria

Flacourtia indica

Gardemia latifolia
Lagerstroemia parviflora

Lannea grandis

Madhuca latifolia

Mitragyna parviflora

Ougenia oogenensis

Phyllanthus embelica

Pterocarpus marsupium

Schleichera oleosa

Semecarpus anacardium

Stereospermum spp

Syzygium cuminii

Tectona grandis

Terminalia bellerica

Terminalia chebula

Terminalia tomentosa

Xylia xylocarpa

Ziziphus mauritiana

Ziziphus xylocarpus 


\section{Conclusions:}

NTFPs were recognized as the major source of livelihood in the remote areas which are in the vicinity of forests, where there is a limited source of livelihood i.e. traditional agriculture practices on limited land. The role of NTFP in a rural and tribal economy is immense and over 3,00o plant species extracted from forests and associated ecosystems have been recorded in India (Tewari, 1994). FAO (1997) also identified NTFPs as the major source of $(80 \%)$ subsistence for rural communities of developing countries along with the agricultural economy. There are various studies which estimated the contribution of NTFPs to the total income of the household ( $>60 \%$ Pandey \& Shukla, 1993; 40\% Chopra 1997; 30-40 \% by Shylajan \& Mythili, 2007). In addition to this medicinal plant supply to pharmaceutical industries is mostly (> 90\%) from wild/ natural forests (Pandey \& Saini, 2008). Moreover, it has been reported that role of NTFP production is not separate from conservation of forests. Extraction of NTFPs like the tapping of gum exudates, plucking leaves, flowers, fruits etc.is comparatively less damaging than the timber (felling trees). In India as per the provision of National Forest Policy (1988) and implementation of JFM resolution people's participation for conservation and sustainable utilization/ harvesting of forest resources/ NTFPs has gained additional impetus, in which NTFP extraction constitutes an attractive economic incentive for local people (Kothari et al., 1997; Ravindranath et al., 2000). But the worst part noticed in it is that these user community members are unaware of their rights and responsibilities towards forest conservation, as a result, there is an imbalance in resource availability and utilization (Saini, 2014). Unawareness among the user's communities about the ecological population of many of the NTFP species in natural forests and existing threat from the destructive harvesting practices also observed as an important factor which has to be taken care for the betterment of forest resources. Therefore, there is a need to aware the user communities with the impact of overharvesting on regeneration status of the species and reestablish a linkage between forest resource extraction and ecological sustainability of various species. Some studies were reported from Biligiri Rangaswamy Temple Wildlife Sanctuary in which analysis of impact of harvesting on regeneration status was studied for Phyllanthus indof ischeri, Strychnos potatorum, Terminalia bellerica and T. chebulawere made (Shaankar et al., 2001; Shankar et al., 1998; Sinha, 2000), and Koliyal (1997) in South India. Similar studies were also reported from tropical forests of Central India for some herb, shrub, climber and fruiting tree species and find that regeneration potential varies from species to species (Pandey and Saini, 2008). As in case of herbaceous species Chlorophytum tuberosum harvesting limit in natural forests is only $30 \%$, whereas in case of for Asparagus racemosus harvesting limit of $52 \%$ seems to be sustainable and in Embelia robusta (small tree), harvesting of $80 \%$ of mature seeds also found sustainable (Pandey and Saini, 2008). It has also reported that regeneration potential depends largely on harvesting rate but along with this harvesting pattern/ technique and time of harvesting also play an important role in the sustainability of plant species (collection after seed maturation) in-situ.

However, along with over and destructive harvesting there are other factors responsible for declining population of utilizable plant species like grazing, fire, and extraction of fuelwood and illicit felling etc. which have a direct impact on the growth and regeneration pattern of plant species. The present study area is of the tropical dry deciduous forest, where people use fire to clear the ground for an easy collection of NTFPs (Flowers of Madhuca latifolia). Sometimes, this fire became uncontrolled, which damaged the forest vegetation of seedling and sapling stage along with freshly fallen seeds and litter etc. It has also been reported by other researchers in Mandla district (Chaubey, 2012) that causes of declining trend of regeneration were high biotic pressure, ignorance of traditional sustainable harvesting practices, destruction of habitat, competition for collection among community members, poverty, increasing population, limited number of fruiting trees, and over and above all is immature, and destructive harvesting trend. It has been experienced during field studies that the users' community members' were unaware of the impact of destructive harvesting and ignorance of sustainable harvest levels is prevalent among them.

Therefore, an observed declining trend of regeneration in the present study for commercially important species could also be associated with destructive and overharvesting along with other environmental stresses, such as grazing impacts, invasion of exotic species and resource deficiencies. There is a need of extensive study in which regeneration status to be evaluated based on harvesting pattern, population and health status of trees including vigour of seed production and other biotic factors. In a nut shell, it could be said that there is need of species specific sufficient data on phenology, ecological functions etc. to develop conservation measures / strategic planning which should be forest as well as people oriented. Integrated approach with active participation of users' communities to be developed by recovering the traditional knowledge of sustainable harvesting, appropriate tools and techniques along with safety measures to be established for improving the status of depleting forest resources. There is a need of developing appropriate tools of monitoring from which prevailing status of plant species, their growth and existing threats etc. to be assessed and timely measures to beadopted.

Acknowledgements:

Authors are highly thankful to the USAID for the financial assistance provided for the entire course of study and inspiration 
Table-2: Status of NTFPs in various sub-impact zones.what does mean by sub-impact zones*

\begin{tabular}{|c|c|c|c|c|c|c|c|c|c|c|c|c|c|c|}
\hline \multirow{2}{*}{$\begin{array}{l}\text { S. } \\
\text { No. }\end{array}$} & \multirow{2}{*}{$\begin{array}{l}\text { Scientific Name } \\
\text { Name }\end{array}$} & \multirow{2}{*}{$\begin{array}{l}\text { Local } \\
\text { Name }\end{array}$} & \multirow[b]{2}{*}{ a } & \multicolumn{3}{|c|}{ o-1 km } & \multirow[b]{2}{*}{ a } & \multicolumn{3}{|c|}{$1-3 \mathrm{~km}$} & \multirow[b]{2}{*}{$\mathrm{a}$} & \multicolumn{2}{|c|}{$3-5 \mathrm{~km}$} & \multirow[b]{2}{*}{ d } \\
\hline & & & & $\mathrm{b}$ & C & d & & b & c & d & & & c & \\
\hline 1. & Aegle marmelos & Bael & 5.45 & 18.18 & 0.17 & 5.20 & - & - & - & - & 1.05 & 10.53 & 0.02 & 1.86 \\
\hline 3. & Cassia fistula & Amaltas & 6.36 & 45.45 & 0.11 & 8.63 & 10.0 & 26.67 & 0.11 & 7.16 & - & - & - & - \\
\hline 4. & Catuneregam spinosa & Bhedi & - & - & - & - & - & - & - & - & 0.53 & 5.26 & 0.02 & 0.99 \\
\hline 5. & Diospyros melanoxylon & Tendu & 22.73 & 63.64 & 0.35 & $17 \cdot 56$ & 21.33 & 46.67 & 0.39 & 15.06 & 66.84 & 63.16 & 1.61 & 35.83 \\
\hline 8. & Phyllanthus embelica & Aonla & - & - & - & - & 2.00 & 20.00 & 0.23 & 4.85 & 3.68 & 42.11 & 0.09 & 7.28 \\
\hline 9. & Schleichera oleosa & Kosum & 5.45 & 36.36 & 0.50 & 9.96 & $3 \cdot 33$ & $33 \cdot 33$ & 0.30 & $7 \cdot 53$ & $1.5^{8}$ & $15 \cdot 79$ & 0.09 & 3.11 \\
\hline 10. & Semecarpus anacardium & Bhilma & $4 \cdot 55$ & 36.36 & 0.34 & 8.54 & 1.33 & 13.33 & 0.06 & 2.64 & 4.21 & 15.79 & 0.22 & $4 \cdot 50$ \\
\hline 11. & Syzygium cumini & Jamun & - & - & - & - & 2.00 & 20.00 & 0.09 & 3.93 & $4 \cdot 74$ & 15.79 & 0.34 & $5 \cdot 3$ \\
\hline 12. & Terminalia Billerica & Baheda & - & - & - & - & 4.00 & 20.00 & 0.14 & 4.83 & 2.63 & 21.05 & 0.14 & 4.40 \\
\hline
\end{tabular}

*Impact zone is the area where local users harvest the forest resources, ( $\sim 5 \mathrm{~km}$ from habitation site) Further zonation : sub-impact zones i) up to o-1 km; ii) 1-3 km is moderate; iii) beyond $3 \mathrm{~km}$ supposed to be have less biotic pressure.

a-Av.density/ha; b- Frequency \%, c-Av.Basal Area; d-Importance Value Index.

and support provided by the team members of IORA, Ecological Solutions, Pvt. Ltd. New Delhi. Support and cooperation of local users' communities and regional staff of forest department is highly acknowledged as without which this study could not be possible.

Table-3: Status of NTFP species (RMA) showing their regeneration potential. Write the English name of NTFP

\begin{tabular}{|c|c|c|c|c|c|c|c|c|c|}
\hline \multirow{2}{*}{$\begin{array}{ll}\text { Sno Name of Species } \\
\text { 1. A. marmelos }\end{array}$} & \multicolumn{3}{|c|}{ o-1 km S-i Z } & \multicolumn{3}{|c|}{$1-3 \mathrm{kmS}-\mathrm{iZ}$} & \multicolumn{3}{|c|}{ 3-5 kmS-i Z } \\
\hline & $\mathrm{P}$ & A & $\mathrm{P}$ & $\mathrm{A}$ & $\mathrm{P}$ & $\mathrm{P}$ & $\mathrm{P}$ & $\mathrm{P}$ & $\mathrm{P}$ \\
\hline 2. B. lanzan & $\mathrm{P}$ & $\mathrm{P}$ & $P$ & $P$ & $\mathrm{P}$ & $\mathrm{P}$ & $P$ & A & $\mathrm{P}$ \\
\hline 3. M. latifolia & $\mathrm{P}$ & $\mathrm{A}$ & $\mathrm{P}$ & $\mathrm{P}$ & $\mathrm{P}$ & $\mathrm{P}$ & $\mathrm{P}$ & $\mathrm{P}$ & $\mathrm{A}$ \\
\hline 4. P. embelica & A & $\mathrm{A}$ & $\mathrm{A}$ & $\mathrm{P}$ & $\mathrm{P}$ & $\mathrm{P}$ & $\mathrm{P}$ & $\mathrm{P}$ & $\mathrm{A}$ \\
\hline 5. S. anacardium & $\mathrm{P}$ & $\mathrm{P}$ & $\mathrm{P}$ & $\mathrm{P}$ & $\mathrm{P}$ & A & $\mathrm{P}$ & A & A \\
\hline 6. S.cumini & $\mathrm{A}$ & $\mathrm{A}$ & $\mathrm{A}$ & $\mathrm{P}$ & $\mathrm{P}$ & $\mathrm{P}$ & $\mathrm{P}$ & $\mathrm{P}$ & $\mathrm{P}$ \\
\hline 7. T. chebula & $\mathrm{P}$ & $\mathrm{P}$ & $\mathrm{P}$ & $\mathrm{P}$ & $\mathrm{P}$ & $\mathrm{P}$ & $\mathrm{P}$ & $\mathrm{P}$ & $\mathrm{P}$ \\
\hline 8. T.indicus & $\mathrm{A}$ & $\mathrm{A}$ & A & $\mathrm{A}$ & $\mathrm{A}$ & $\mathrm{A}$ & $\mathrm{A}$ & $\mathrm{A}$ & A \\
\hline
\end{tabular}

A-absent indicating threat to the species;

P-shows the presence of the species.

\section{References:}

Chaubey, O.P. (2012): Eco-silviculture options for sustainable management in joint forest management - A case study of mixed forests of Madhya Pradesh, India. Int. J. Biosci. Biotech., 4(1):33-48.

Dikshit, S.S. Kala, C.P. (2014): Traditional Utilization and Harvesting of Medicinal Plants in Mandla District of Madhya Pradesh. Appl. Ecol. Environ. Sci. 2(2):48-53.

Gautam, R.S., Kumar, A., Kumar, S. \& Singh, D. (2014): Training Report on- Understanding Livelihood Opportunities: Mandla district, Madhya Pradesh. Submitted at: Institute of Livelihood Research and Training, Bhopal, M.P., India.

Greig, S.P. (1983): Quantitative Plant Ecology. Third Edition, University of California Press, Berkley and Los Angeles.

Kala, C.P. (2011): Indigenous Uses and sustainable Harvesting of Trees by Local People in Panchmarhi Biosphere reserve of India. Int. J. Med. Arom. Plant., 1(2):153-161
Kaushal, K.K. \& Kala, J.C. (2004): Applying the sustainable livelihood approach to Joint Forest Management Projects in India. Int. For. Rev., - b., (1):13-18.

Malhotra, K.C., Deb, D., Dutta, M., Vasula, T.S., Yadav, G. \& Adhikari, M. (1991): Research Report on- Role of non-timber forest produce in village economy. A household survey in Jamboni Range, Midnapore, West Bengal, Submitted by: Indian Institute of Bio-social Research and Development (IBRAD), Calcutta, India.

MoEF, (2006): Annual Report of Ministry of Environment and Forests, Govt. of India.

Mishra, R. (1968): Ecology Work Book. Oxford and IBH Publishing Company. New Delhi.

Mukherjee, A.K. (1994): India's Forests: A status report: concepts, definitions, trends, controversies, Paper Presented for the International Workshop on India's Forests Management and Ecological Revival, New Delhi 10-12, February, 1994.

Pandey, R.K. (2009): Status of NTFPs in natural forests of Madhya Pradesh Research Report of SFRI, Jabalpur, Madhya Pradesh. Submitted to MPMFP federation, Bhopal.

Pandey, R.K. \& Saini, S.K. (20o8): Development of natural resource information system in tribal district of Madhya Pradesh. Research Report of SFRI, Jabalpur, Madhya Pradesh. Submitted to CSIR, Govt. of India.

Prasad R. Bhatnagar, P. (1991): Socio-economic Potential of Minor Forest Produce in Madhya Pradesh. State Forest Research Institute, Bulletin No.26, Jabalpur.

Prasad, R., Kotwal, P. and Mishra, M.(2002). Impact of Harvesting of Embelica officinalis (Aonla) on Natural Regenaration, Health, Vitality and Ecosystem in Central Indian Forest.J. Sustain. For., 14(4):1-12.

Shrivastava, R.K. (2010): Working Plan of East Mandla Forest Division for 2010-11 to 2019-2020. Centre Circle Jabalpur, Madhya Pradesh: Madhya Pradesh Government, Forest Department. 